\title{
FAKTOR-FAKTOR YANG MEMPENGARUHI MANAJEMEN LABA PERUSAHAAN PUBLIK DI INDONESIA PADA TAHUN 2008
}

\author{
Yanuar Nanok S. ${ }^{1}$ \\ UNIKA Atma Jaya Jakarta \\ Natasya $^{2}$ \\ UNIKA Atma Jaya Jakarta ${ }^{2}$ \\ Brigitta Azaria Widadi ${ }^{3}$ \\ UNIKA Atma Jaya Jakarta
}

\begin{abstract}
Financial report are one of the measurement for company achivement and income is the easiest and one of the most usefull kriteria for company performance. One alternative to make financial report look good for investor, usually company use income smoothing for window dressing. Using 219 company in Indonesian stock exchange at 2008, we can assume that size of the company, leverage, accounting public, and operating cash flow are the significant variabel to make manajemen create income smoothing. We can concluded, with good control, owners can push manajemen to create financial report more transparant.
\end{abstract}

Keywords: income smoothing, size, accounting public, independent commisionaire, leverage, manajemen ownership, operating cash flow.

\footnotetext{
1, 2, 3 Yanuar Nanok S. is a faculty of UNIKA Atma Jaya (yanuar.nanok@atmajaya.ac.id) and Natasya \& Brigitta Azaria Widadi are alumni of UNIKA Atma Jaya Jakarta.
}

60) S., Yanuar N.,Natasya,W.Brigitta A. / Journal of Applied Finance and Accounting 3(1) 60-74 


\section{LATAR BELAKANG}

Laporan keuangan diharapkan dapat menyediakan informasi mengenai kinerja keuangan perusahaan dan bagaimana manajemen perusahaan bertanggung jawab kepada pemilik. Laporan keuangan tersebut diharapkan dapat memberikan informasi kepada para investor dan kreditor dalam mengambil keputusan yang berkaitan dengan investasi dana mereka (Halim et.al. 2005). Akan tetapi informasi yang disampaikan terkadang diterima tidak sesuai dengan kondisi perusahaan sebenarnya. Dalam kondisi yang demikian ini dikenal sebagai informasi yang tidak simetris atau asimetri informasi (asymmetric information) (Haris, 2004). Adanya asimetri antara manajemen (agent) dengan pemilik (principal) akan memberi kesempatan kepada manajer untuk melakukan manajemen laba (earnings management) (Richardson, 1998).

Ada beberapa tindakan manajemen laba yang telah terungkap dalam beberapa kasus skandal pelaporan akuntansi yang secara luas diketahui, antara lain Enron, Merck, WorldCom dan mayoritas perusahaan lain di Amerika Serikat (Cornett et al, 2006). Selain itu, di Indonesia juga terjadi hal serupa, seperti PT. Lippo Tbk dan PT. Kimia Farma Tbk juga melibatkan pelaporan keuangan (financial reporting) yang berawal dari terdeteksi adanya manipulasi (Gideon, 2005). Manajemen laba yang dilakukan dan menyebabkan terjadinya kasus-kasus diatas merupakan perilaku yang tidak dapat diterima, karena manajemen laba yang terjadi mengakibatkan suatu pengurangan dalam keandalan informasi laporan keuangan. Investor mungkin tidak menerima informasi yang cukup akurat mengenai laba untuk mengevaluasi return dan risiko portofolionya (Ashari et.al., 1994) dalam Assih (2004).

Leeuz et.al., (2002) menemukan bahwa tingkat manajemen laba di indonesia relatif tinggi (rangking ke 15 terbesar diantara 31 negara) dengan menggunakan data antara tahun 1990 sampai 1999. Rangking manajemen laba Indonesia tersebut berada di atas Thailand, Malaysia dan Filipina. Mitra (2002), Koh (2003), dan Midiastuty \& Machfoedz (2003) menemukan bahwa kehadiran kepemilikan institusional yang tinggi membatasi manager untuk melakukan manajemen laba. Hal ini serupa dengan kepemilikan manajerial, dimana semakin banyaknya saham yang dimiliki oleh manajer maka akan kecenderungan melakukan manajemen 
labanya juga kecil. Penelitian Jensen dan Meckeling (1976) menyatakan bahwa terdapat kesejajaran antara kepentingan manajer dan pemegang saham pada saat manajer memiliki saham perusahaan dalam jumlah yang besar. Yang et al. menemukan bahwa ukuran perusahaan memiliki hubungan positif dan signifikan. Vafeas (2000) mengatakan bahwa selain kepemilikan manajerial, peranan dewan komisaris juga diharapkan dapat meningkatkan kualitas laba dengan membatasi manajemen laba melalui fungsi monitoring atas pelaporan keuangan. Chtourou dkk (2001) dan Wedari (2004) menemukan bahwa dewan komisaris yang independen akan membatasi aktivitas manajemen laba. Xie, Davidson, dan Dadalt (2003) menemukan bahwa presentase dewan komisaris dari luar perusahaan yang independen berpengaruh negatif secara signifikan terhadap akrual kelolaan. Agnes Utari Widyaningdyah (2001) menemukan hubungan positif antara leverage dengan manajemen laba.

\section{LANDASAN TEORI}

Schipper (1989) mendefinisikan manajemen laba sebagai suatu intervensi dengan maksud tertentu terhadap proses pelaporan keuangan eksternal dengan sengaja untuk memperoleh beberapa keuntungan pribadi. Fischer dan Rosenzweig (1995) mendefinisikan manajemen laba sebagai tindakan seorang manajer dengan menyajikan laporan yang menaikan (menurunkan) laba periode berjalan dari unit usaha yang menjadi tanggungjawabnya, tanpa menimbulkan kenaikan (penurunan) profitabilitas ekonomi unit tersebut dalam jangka panjang. Dechow, et.al (1996) mendefinisikan earnings management sebagai earnings manipulation, baik di dalam maupun di luar batas Generally Accepted Accounting Principles (GAAP). Scott (1997) mendefinisikan earnings management sebagai tindakan manajemen untuk memilih kebijakan akuntansi dari suatu standar tertentu dengan tujuan memaksimalkan kesejahteraan dan atau nilai pasar perusahaan. Setiawati dan Na'im, (2000) mendefinisikan manajemen laba sebagai campur tangan dalam proses pelaporan keuangan eksternal dengan tujuan untuk menguntungkan diri sendiri.

62) S., Yanuar N.,Natasya,W.Brigitta A. / Journal of Applied Finance and Accounting 3(1) 60-74 
Penelitian Jensen dan Meckeling (1976) menyatakan bahwa terdapat kesejajaran antara kepentingan manajer dan pemegang saham pada saat manajer memiliki saham perusahaan dalam jumlah yang besar. Jensen dan Meckling (1976) berpendapat bahwa pemisahan antara kepemilikan saham dan pengawasan perusahaan menimbulkan benturan kepentingan antara pemegang saham dan pihak manajemen. Benturan ini meningkat ketika pihak manajemen mempunyai dorongan untuk meningkatan kemakmurannya sendiri. Pada saat proporsi kepemilikan manajerial meningkat, kepentingan dari pemegang saham dan manajemen mulai menyatu. Smith (1976) menemukan bahwa manajemen laba secara signifikan lebih sering dilakukan oleh perusahaan - perusahaan yang dikendalikan oleh manajer dibandingkan dengan perusahaan - perusahaan yang dikendalikan oleh pemiliknya.

Penelitian Dhaliwal et al. (1982), dan Morck et al. (1988) memberikan simpulan bahwa perusahaan yang dikelola oleh manajer yang memiliki persentase tertentu saham perusahaan dapat mempengaruhi tindakan manajemen laba. Penelitian Warfield et al. (1995) menemukan bahwa jumlah proporsi kepemilikan saham manajemen di suatu perusahaan memiliki hubungan positif terhadap tindakan manajemen laba.

Dalam hubungan dengan operating cashflow, penelitian Dechow et al. (1995) yang menemukan bahwa discretionary akrual memiliki korelasi negatif dengan arus kas operasi. Penelitian ini konsisten dengan. Becker et al. (1998) melaporkan adanya hubungan negatif antara arus kas operasi dengan dan akrual diskresioner.

Moses (1997) mengemukakan bahwa perusahaan-perusahaan yang lebih besar memiliki dorongan yang lebih besar untuk melakukan perataan laba (salah satu bentuk manajemen laba) dibandingkan dengan perusahaan kecil, karena memiliki biaya politik lebih besar, Biaya politik muncul dikarenakan profitabilitas perusahaan yang tinggi sehingga dapat menarik perhatian media dan konsumen.

Peasnell et al. (1998) meneliti efektifitas dewan komisaris dan komisaris independen terhadap manajemen laba yang terjadi di Inggris. Dengan menggunakan sampel penelitian yang terdiri dari 1178 perusahaan tahun selama periode 1993-1996, hasil penelitian ini menunjukkan bahwa 
keberadaan komisaris independen membatasi pihak manajemen untuk melakukan manajemen laba. Vafeas (2000) mengatakan bahwa selain kepemilikan manajerial, peranan dewan komisaris juga diharapkan dapat meningkatkan kualitas laba dengan membatasi manajemen laba melalui fungsi monitoring atas pelaporan keuangan.

Becker dkk (1998) menyimpulkan bahwa klien dari auditor Non Big 6 melaporkan akrual diskresioner (proxy dari manajemen laba) secara ratarata lebih tinggi dari yang dilaporkan oleh oleh klien auditor Big 6. Francis dkk (1999) juga menemukan hasil yang konsisten. Selain itu Myers dan Skinner (2000) menemukan bukti empiris bahwa perusahaan berukuran besar cenderung tidak melaporkan accurate earnings setelah meneliti pertumbuhan earnings mereka selama 14 kuarter.

Peneliti Marachi (2001) di Amerika Serikat dengan menggunakan data sample perusahaan industry tahun 1996 menemukan bahwa ukuran perusahaan memiliki hubungan negatif terhadap manajemen laba. Penelitian ini sejalan dengan hasil dari penlitian Lee \& Choi (2002) yang mengemukakan bahwa perusahaan yang berkuran kecil cenderung lebih terdorong untuk melakukan tindakan manajemen laba. Sejalan dengan penelitian Myers dan Skinner sebelumnya, Barton and Simko (2002) juga menemukan bahwa perusahaan berukuran besar cenderung mendapat tekanan-tekanan untuk memenuhi harapan pasar sehingga mereka terdorong untuk melakukan manajemen laba. Selain itu perusahaan besar juga memiliki "bargaining power" yang lebih besar untuk bernegosiasi dengan auditor untuk melakukan manajemen laba. Penelitian lebih lanjut tentang kepemilikan manajerial yang dilakukan Gabrielsen, et al. (2003) mengemukakan bahwa jumlah kepemilikan saham oleh manajer akan mempengaruhi tindakan manajemen laba.

\section{DEFINISI OPERASIONAL VARIABEL}

Manajemen Laba: Manajemen laba pada penelitian ini dilihat berdasarkan total akrual diskresioner yang terdapat dalam sebuah laporan keuangan suatu perusahaan. Untuk memisahkan antara komponen total akrual diskresioner dan non diskresioner maka peneliti menggunakan

64) S., Yanuar N.,Natasya,W.Brigitta A. / Journal of Applied Finance and Accounting 3(1) 60-74 
model Jones yang dimodifikasi. Model Jones yang dimodifikasi (Dechow,1995). Model ini digunakan dalam penelitian-penelitan manajemen laba sebelumnya seperti oleh Nasser (2008), Yang Et.al (2007) dan Myers\& Skinner (2000).

Kepemilikan Manajerial Dalam penelitian Smith (1976), Dhaliwal et al. (1982), Morck et al. (1988), Gabrielsen et al. (2003), Nasser (2008) menemukan adanya pengaruh kepemilikan manajerial terhadap manajemen laba. Mitra (2002), Koh (2003) dan Midiastuty \& Machfoedz (2003) menunjukkan kepemilikan manajerial berpengaruh secara negatif Sedangkan hasil Werfield et al. (1995), Wedari (2004), Setyo (2005) dan menemukan adanya pengaruh secara positif.

$\mathrm{Ha}_{1}$ : kepemilikan manajerial berpengaruh terhadap manajemen laba.

Ukuran Perusahaan Marachi (2001), Lee \& Choi (2002), dan Nasser (2008) menemukan adanya pengaruh secara negatif pada ukuran perusahaan terhadap manajemen laba. Sedangkan Moses (1997), Myers dan Skinner (2000), Barton and Simko (2002), serta Yang et al. (2007) mengemukakan bahwa ukuran perusahaan berpengaruh secara positif.

$\mathrm{Ha}_{2}$ : ukuran perusahaan berpengaruh secara positif terhadap manajemen laba.

Proporsi Dewan Komisaris Independen Peasnell (1998), Vafeas (2000), Chtourou (2001), Wedari (2004), Suranta (2004), Wilopo (2004), dan Nasser (2008) menemukan bahwa proporsi dewan komisaris independen memiliki hubungan yang negatif terhadap manajemen laba

$\mathrm{Ha}_{3}$ : proporsi dewan komisaris independen berpengaruh secara negatif terhadap manajemen laba.

Ukuran KAP Becker et al.(1998) dan Francis et al.(1999) menemukan bahwa ukuran KAP memiliki pengaruh terhadap manajemen laba. Sedagkan Siregar \& Utama (2005) dalam penelitiannya memperoleh hasil yang berbeda mengenai hubungan antara ukuran KAP dengan manajemen laba, dimana ukuran KAP dinilai tidak memiliki pengaruh signifikan terhadap kebijakan manajemen laba.

$\mathrm{Ha}_{4}$ : ukuran KAP berpengaruh terhadap manajemen laba. 
Leverage Penelitian Ashari (1994), Zuhroh (1996), Widyaningdyah (2001), Halim et al. (2005), Siregar \& Utama (2005), dan Nasser (2008) menemukan bahwa leverage memiliki hubungan yang positif dengan manajemen laba.

$\mathrm{Ha}_{5}$ : leverage berpengaruh secara positif terhadap manajemen laba.

Arus Kas Operasi Penelitian Dechow (1995) dan Becker et al. (1998) menemukan adanya hubungan yang negatif antara arus kas operasi dengan manajemen laba.

$\mathrm{Ha}_{6}$ : arus kas operasi berpengaruh secara negatif terhadap manajemen laba.

Dari variabel-variabel tersebut maka dibuatlah suatu model hubungan antara variabel bebas dan variabel terikatnya. Model yang akan digunakan adalah sebagai berikut:

\section{Manajemen laba $=f(K e p e m i l i k a n$ manajerial, ukuran perusahaan, proporsi dewan komisaris independen, Ukuran KAP, leverage, arus kas operasi)}

Pengujian dilakukan secara cross sectional, dengan mempertimbangkan bahwa setiap periode memiliki kondisi dan faktor makro yang berbeda. Diharapkan bahwa penelitian yang hanya satu tahun (2002)-kecuali untuk laba yang memperhitungkan tahun sebelumnya-memberikan gambaran yang lebih jelas tanpa terganggu faktor-faktor tersebut

Variabel-variabel bebas yang dipilih akan diuji apakah mempunyai pengaruh terhadap variabel terikatnya. Selain itu dilihat pula seberapa besar pengaruhnya dan bagaimana hubungan antara variabel bebas dengan variable terikatnya apakah searah (positif) atau justru berbanding terbalik (negatif).

Penelitian ini akan meneliti hubungan antara Manajemen laba sebagai variabel terikat dan enam variabel bebas, yaitu kepemilikan manajerial, ukuran perusahaan, proporsi dewan komisaris independen, ukuran Kantor Akuntan Publik dan arus kas operasi

66) S., Yanuar N.,Natasya,W.Brigitta A. / Journal of Applied Finance and Accounting 3(1) 60-74 
Pengujian dilakukan dengan metode analisis regresi berganda. Penggunaan metode ini sejalan dengan penelitian milik Nasser (2008), dan juga untuk memberikan gambaran tentang faktor-faktor yang mempengaruhi manajemen laba di Indonesia.

Model penelitian yang digunakan pada penelitian ini adalah:

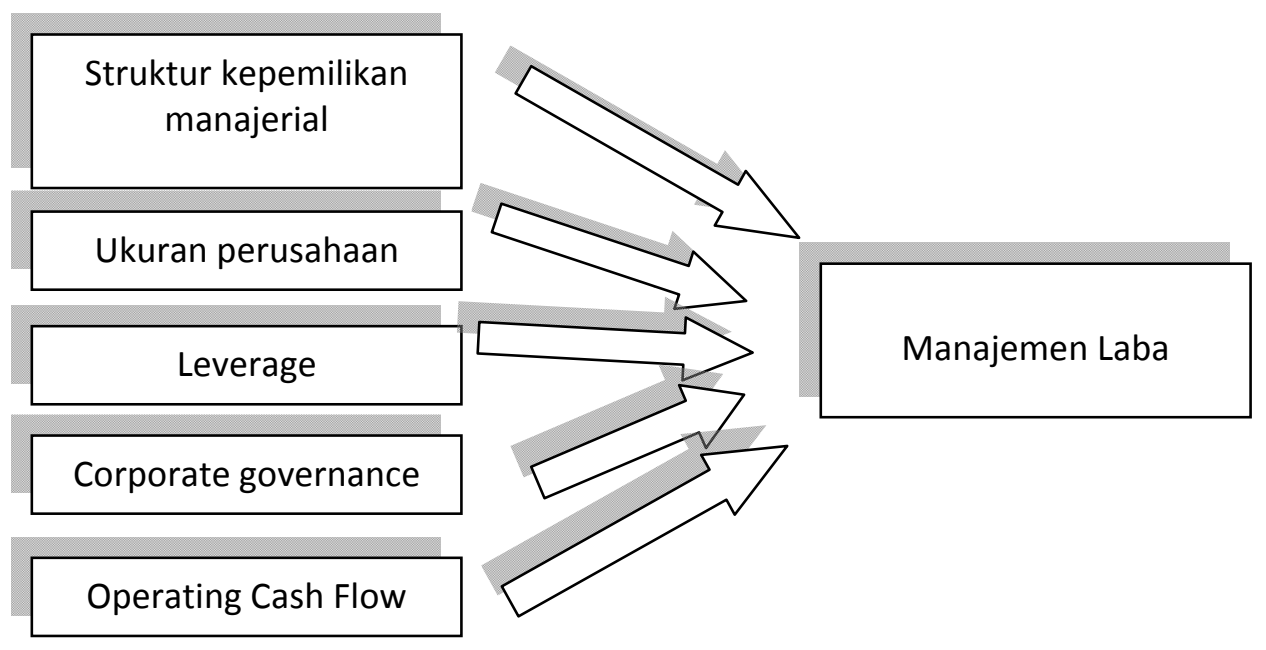

Gambar 1. Model Penelitian

\section{HASIL DAN PEMBAHASAN}

Dari capital market direktori tahun 2009 terdapat 386 perusahaan yang terdaftar di Bursa Efek Indonesia pada tahun 2008. Dengan mengesampikan perusahaan yang bergerak dibidang keuangan dan perusahaan yang memiliki tutup buku tidak pada desember 2008, maka terdapat 270 perusahaan yang memiliki data yang lengkap. Setelah pengurangan yang dilakukan untuk mendapatkan data yang normal maka digunakan 219 data.

Hasil analisis dari multiple regression -yang meliputi nilai R-square, Fvalue, koefisien parameter dan t-value dari parameter yang ada- dapat dilihat pada tabel 1. 
Tabel 1. Hasil Regresi untuk Model yang Diuji

\begin{tabular}{lrr}
\hline \multicolumn{1}{c}{ Variable } & Beta & p-value \\
\hline Constant & & $-0,54$ \\
Kepemilikan manajerial & 0,022 & 0,35 \\
Ukuran perusahaan & 0,410 & $5,290^{* * *}$ \\
Komisaris Independen & 0,001 & 0,022 \\
Kantor Akuntan Publik & 0,150 & $2,279^{* *}$ \\
Leverage & 0,102 & $1,650^{*}$ \\
Operating Cash Flow & $-0,585$ & $-7,219^{* * *}$ \\
R-square & 0,217 & \\
Adj R-square & 0,195 & \\
F-test & 9,842 & \\
Durbin-Watson & 2,151 & \\
p-value & 0,000 & \\
\hline
\end{tabular}

*** signifikan pada level $1 \%$

** signifikan pada level $5 \%$

* signifikan pada level $10 \%$

Dari uji $t$ statistik diperoleh bahwa dari 6 hipotesis yang diajukan, 4 hipotesis berpengaruh signifikan dan 2 hipotesis tidak signifikan. Penjabarannya adalah sebagai berikut:

\section{Kepemilikan Manajerial}

Berdasarkan hasil uji $t$ diperoleh bahwa hipotesis pertama ditolak, yang berarti bahwa tidak ada beda manajemen laba untuk kepemilikan manajerial.

Hasil penelitian ini sejalan dengan penelitian Astuti (2003) yang menemukan bahwa tidak ada beda kebijakan manjemen laba untuk kepemilikan manajerial yang berbeda.

Hasil ini bertentangan dengan penelitian penelitian Warfield et al. (1995) yang menemukan bahwa jumlah proporsi kepemilikan saham manajemen di suatu perusahaan memiliki hubungan positif terhadap tindakan manajemen laba. Sebelumnya penelitian Dhaliwal et al. (1982), dan Morck et al. (1988) memberikan simpulan bahwa perusahaan yang dikelola oleh manajer yang memiliki persentase tertentu saham perusahaan dapat mempengaruhi tindakan manajemen laba. Penelitian ini juga 68) S.,Yanuar N.,Natasya,W.Brigitta A. / Journal of Applied Finance and Accounting 3(1) 60-74 
menemukan hasil yang berbeda dari penelitian yang dilakukan oleh Mitra (2002), Koh (2003), dan Midiastuty \& Machfoedz (2003) yang menemukan bahwa dengan kepemilikan manajerial yang tinggi akan membatasi manager untuk melakukan manajemen laba. Dimana semakin banyaknya saham yang dimiliki oleh manajer maka kecenderungan untuk melakukan manajemen labanya juga kecil.

\section{Ukuran Perusahaan}

Hasil analisis menyatakan bahwa variabel ukuran perusahaan berpengaruh secara positif terhadap manajemen laba. Hasil penelitian ini sejalan dengan penelitian Barton and Simko (2002) yang mengindikasikan bahwa perusahaan berukuran besar cenderung mendapat tekanan-tekanan untuk memenuhi harapan pasar sehingga mereka terdorong untuk melakukan manajemen laba. Selain itu perusahaan besar juga memiliki "bargaining power" yang lebih besar untuk bernegosiasi dengan auditor untuk melakukan manajemen laba. Pendapat ini didukung oleh penelitian Nelson et al. (2002) yang menemukan auditor-auditor yang melakukan manajemen laba untuk klien-klien dari perusahaan besar. Selain itu Myers dan Skinner (2000) menemukan bukti empiris bahwa perusahaan berukuran besar cenderung tidak melaporkan accurate earnings setelah meneliti pertumbuhan earnings mereka selama 14 kuarter.

\section{Proporsi Dewan Komisaris}

Sesuai dengan hasil pengujian statistik yang terdapat pada tabel 4.8, proporsi dewan komisaris memiliki pengaruh yang positif tetapi tidak signifikan terhadap manajemen laba. Hasil penelitian ini bertentangan dengan penelitian dilakukan oleh Chtourou dkk (2001) dan Wedari (2004) yang menemukan bahwa dewan komisaris yang independen akan membatasi aktivitas manajemen laba. Selain itu dari hasil analisis Wilopo (2004) tentang hubungan dewan komisaris independen, komite audit, kinerja perusahaan dan akrual diskresioner didapatkan bahwa kehadiran dewan komisaris independen mampu mempengaruhi secara negatif praktik manajemen laba di perusahaan.

Hasil penelitian ini sama dengan hasil penelitian yang dilakukan oleh Siregar dan Utama (2005) serta Boediono (2005) yang mengindikasikan bahwa poporsi komisaris Independen yang tinggi tidak terbukti dapat membatasi tindakan manajemen laba yang dilakukan oleh perusahaan. 


\section{Ukuran KAP}

Hasil penelitian menyatakan bahwa hipotesis keempat diterima. Hasil penelitian ini menjelaskan bahwa kebijakan manajemen laba yang diaudit KAP big four berbeda dengan kebijakan manajemen laba yang diaudit KAP non-big four. Becker dkk (1998) menyimpulkan bahwa klien dari auditor Non Big 6 melaporkan akrual diskresioner (proxy dari manajemen laba) secara rata-rata lebih tinggi dari yang dilaporkan oleh oleh klien auditor Big 6. Francis dkk (1999) juga menemukan hasil yang konsisten.

Hasil penelitian ini didukung oleh Gore et al. (2001) yang melaporkan bahwa perusahaan yang diaudit oleh KAP non-big 5 cenderung lebih banyak yang melakukan earnings management dibanding perusahaan yang diaudit KAP big 5. Selain itu Lennox (1999) juga menemukan bahwa laporan audit yang dikeluarkan oleh auditor dari KAP big 5, laporannya dinilai lebih informatif. Hal ini meyangkut hubungan positif antara ukuran KAP dengan akurasi hasil audit.

\section{Leverage}

Sesuai dengan hasil pengujian yang terdapat pada tabel 4.8, Leverage memiliki pengaruh postif dan signifikan terhadap manajemen laba. Hasil ini sesuai dengan penelitian Watts \& Zimmerman (1986) menyatakan bahwa perusahaan dengan rasio hutang tinggi cenderung menggunakan prosedur akuntansi yang bersifat meningkatkan laba (income-incresing). Hasil penelitian Watts \& Zimmerman ini sejalan dengan teori debt covenance yang menyatakan bahwa manajer termotivasi melakukan manajemen laba untuk menghindari pelanggaran perjanjian utang. Manajemen diduga akan memilih prosedur akuntansi yang meningkatkan aktiva, mengurangi utang dan meningkatkan pendapatan dengan tujuan untuk menghindari pelanggaran debt-covenant. Teori ini juga didukung oleh penelitian Guenther (1994), Utari Widyaningdyah (2001) dan Halim et al (2005) yang menemukan hubungan positif antara leverage dan manajemen laba.

\section{Arus Kas Operasi}

Berdasarkan hasil pengujian yang dilakukan diperoleh bahwa arus kas operasi (CFO) berpengaruh signifikan terhadap manajemen laba. Hasil penelitian ini sesuai dengan penelitian yang dilakukan oleh Dechow

70) S.,Yanuar N.,Natasya,W.Brigitta A. / Journal of Applied Finance and Accounting 3(1) 60-74 
(1995) dan Becker et al. (1998) menemukan adanya hubungan yang negatif antara arus kas operasi dengan manajemen laba.

\section{Simpulan}

Hasil penelitian menunjukkan bahwa terdapat empat variabel yang memiliki pengaruh signifikan terhadap manajemen laba yaitu ukuran perusahaan, ukuran KAP, dan arus kas operasi. Sedangkan tiga variabel lainnya yaitu struktur kepemilikan manajerial, proporsi dewan komisaris independen, dan leverage ternyata tidak memiliki pengaruh yang signifikan terhadap manajemen laba.

Dari hasil penelitian tersebut dapat disimpulkan bahwa variabel ukuran perusahaan, ukuran KAP, dan arus kas operasi merupakan faktor-faktor yang dapat mempengaruhi manajemen untuk melakukan tindakan manajemen laba. Di sisi lain variabel struktur kepemilikan manajerial, proporsi dewan komisaris independen, dan leverage ternyata tidak secara signifikan berpengaruh dengan motivasi untuk melakukan tindakan manajemen laba.

\section{DAFTAR PUSTAKA}

Ashari, Nasuhiyah, Hian Chye Koh, Soh Leh Tan, \& Wfei Har Wong. (1994). Factors Affecting Income Smoothing Among Listed Companies in Singapore. Accounting Business Research, 24(96), 292-301.

Astuti, Dewi S. P. (2003). Analisis Faktor-faktor yang Mempengaruhi Management Laba di Seputar Right Issue. Working Paper. Universitas Slamet Riyadi, Surakarta.

Barton, J., \& P. Simko. (2002). The balance sheet as an earnings management constraint. Accounting Review, 77, 1-27.

Becker, C. L., M.L Defond, J.Jiambalvo, \& K.R. Subramanyam. (1998). The Effect of Audit Quality on Earnings Management. Contemporary Accounting Research, 15, 1-24. 
Dechow, Patricia M., R.G. Sloan \& A.P. Sweeney. (1995). Detecting Earnings Management. The Accounting Review, 70, 193-225.

Francis, J.R., E.L.Maydew, \& H.C. Sparks. (1999). The Role of Big 6 Auditors in the Credible Reporting of Accruals. Auditing: A Journal of Practice and Theory, 18, 17-34.

Gore, P., P. F. Pope, \& A. K. Singh. (2001). Non-audit services, auditor independence, and earnings management. Working Paper, Lancaster University.

Jensen, M.C., \& W.H. Meckling. (1976). Theory of the Firm: Managerial Behaviour, Agency Cost, and Ownership Structure. Journal of Financial Economics.

Jones, J. J. (1991). Earnings Management During Import Relief Investigations. Journal of Accounting Research, 29(2), 193-228.

Koh, P-S. (2003). On the Association between Institusional Ownership and Aggressive Corporate Earnings Management in Australia. The British Accounting Review, 35, 105.

Lee.B.B. and B. Choi. (2002) Company Size, Auditor Type, and Earnings Management. Journal of Forensic Accounting, 3, 27-50.

Lennox, C. (1999). Are large auditors more Accurate than small auditors? Accounting and Business Research, 29, 217-227.

Morck, R., Shlefier, A., \& Vishney, R. (1988). Management Ownership and Market Valuation: An Empirical Analysis. Journal of Financial Economics, 20, 293-316.

Moses, O. D. (1987). Income Smoothing and Incentives: Empirical Test Using Accounting Changes. Accounting Review, 358-377.

Myers, L., \& D.J. Skinner. (2000). Earnings momentum and earnings management. Working Paper, University of Michigan.

72) S.,Yanuar N.,Natasya,W.Brigitta A. / Journal of Applied Finance and Accounting 3(1) 60-74 
Nasser, Etty M. (2008). Pengaruh Struktur Kepemilikan dan Dewan Komisaris Independen Terhadap Nilai Perusahaan dengan Manajemen Laba dan kebijakan Hutang Sebagai Variabel Intervening. Media Riset Akuntansi, Auditing dan Informasi, 8(1), 127.

Richardson, Vernon J. (1988). Information Asymetry and Earnings Management: Some Evidence. Dissertation. University of Kansas.

Schipper, K. (1989). Commentary on Earnings Management. Accounting Horizon, 3, 91-102.

Setiawati, Lilis \& Ainun Na'im. (2000). Manajemen Laba. Jurnal Ekonomi dan Bisnis Indonesia, 15(4), 424-441.

Setyo, Gideon B. Boediono. (2005). Pengaruh Mekanisme Corporate Governance Terhadap Manajemen Laba dan Dampaknya Pada Kualitas Laba. Jurnal Akuntans, Th.IX.

Subramanyam, K.R. (1996). The Pricing of Discretionary Accruals. Journal of Accounting and Economics, 22, 249-281.

Suwito, E \& Herawaty, A. (2005). Analisis Pengaruh Karakteristik Perusahaan Terhadap Tindakan Peratan Laba yang Dilakukan oleh Perusahaan yang Terdaftar di Bursa Efek Jakarta. Jurnal Riset Akuntansi, 5, 136-146.

Veronika, S.N.P. \& Utama, S. (2005). Pengaruh Struktur Kepemilikan, Ukuran Perusahaan, dan Praktek Corporate Governance Terhadap Pengelolaan Laba (Earnings Management). Jurnal Riset Akuntansi Indonesia, 9(3), 307-326.

Wahidwati. (2002). Pengaruh Kepemilikan Manajerial dan Kepemilikan Instititusional pada Kebijakan Hutang Perusahaan: Sebuah Perspektif Theory Agency. Jurnal Riset Akuntansi Indonesia, 5(1), 1-16. 
Wedari, L.K. (2004). Analisis Pengaruh Dewan Komisaris dan Keberadaan Komite Audit Terhadap Manajemen Laba. Makalah Simposium Nasional Akuntansi, 8.

Widyaningdyah A.U. (2001). Analisis Faktor-Faktor Yang Berpengaruh Terhadap Earning Management Pada Perusahaan Go Publik Di Indonesia. Jurnal Akuntansi \& Keuangan, 3(2), 89-101.

74) S., Yanuar N.,Natasya,W.Brigitta A. / Journal of Applied Finance and Accounting 3(1) 60-74 